\title{
Reply by Professor Myint to the Comments on his Paper
}

Professor Myint said that in the first part of his paper he tried to show what were the implications of supposing that comparative costs could be altered. The paper was a modest attempt to show how to move towards future comparative costs.

He had contrasted free trade and protection. But free trade might lead away from comparative costs. This was why he had asked what was the direction in which comparative costs were changing and if one could use the methods of control to get the same result. He was in favour of neo-classical protection to support a genuine growth industry.

He had said little about developed countries because he agreed with UNCTAD. He wanted an outward-looking and free trade approach and lower barriers in rich countries.

On what was the right strategy for poor countries, one could have a safety-first policy of diversification, preferring safety to growth.

On aid, he thought poor countries could expect a given annual amount of aid, but they could not simultaneously be guaranteed a given rate of growth without outside (politically unacceptable) supervision over aid. This was the crux of the problem.

He supported one-way free trade. The rich countries should be internationally minded. He was concerned to show that the poor countries might benefit more by moving further towards two-way free trade.

All who advised poor countries knew the pressure to restrict imports and give tax inducements to foreign firms to set up branches there. Perhaps the alternative was to restrict foreign investment but to encourage freer trade. 